\title{
Evaluation approaches to empowering interventions
}

\section{Az empowerment beavatkozások értékelési módszereinek áttekintése}

\section{ILDIKÓ VOJTEK}

Ildikó Vojtek: University of Pécs, Faculty of Humanities and Social Sciences, "Education and Society" Doctoral School of Education (Hungary); vojtek.ildiko@pte.hu

Vojtek Ildikó: Pécsi Tudományegyetem, Bölcsészet- és Társadalomtudományi Kar, „Oktatás és Társadalom”Neveléstudományi Doktori Iskola; vojtek.ildiko@pte.hu

\begin{abstract}
Empowerment has been a widespread term since the 1990s and is common in contexts as social work, community development, psychology, medicine, and several other areas of human development and health. Empowerment is a process during which a person, an organization, or a community is enabled to identify themselves, to recognize their own power positions and to improve their unequal social situations (Varga, 2017). The evaluation of empowerment outcomes has been missing from the Hungarian professional literature. This review article focuses on the empowerment of adults through educational theatre and drama, and is based on the analysis of previous research results in the area.

Empowerment is a multi-level, context-dependent construct, hence, evaluating empowerment outcomes is challenging. Theorists of empowerment warn against creating a general instrument for measurement (Zimmerman, 1995). I reflect on quantitative, qualitative, and combined evaluation methods, such as the Psychological Empowerment Scale (Akey et al., 2000), the Empowerment Evaluation (Fetterman, 2001), and the Empowerment Measuring Tool (Jupp et al., 2010), also taking Wandersman and associates' (2005) principles for empowerment evaluation into account.
\end{abstract}

Keywords: empowerment intervention, empowerment evaluation, empowerment measurements

\begin{abstract}
Absztrakt
Az empowerment az 1990-es évek óta széles körben használt fogalom, mely napjainkban is gyakran elöfordul többek között a szociális munka, a közösségfejlesztés, a pszichológia és az egészségügy területén. Az empowerment olyan folyamat, amelynek során öntudatosabbá válik a személy, a szervezet, vagy egy közösség, felismeri saját hatalmi pozicióját, és képessé válik egyenlötlen helyzetének megváltoztatására (Varga, 2017). Az empowerment-folyamatok értékelésével kapcsolatban nem érhetö el hazai szakirodalmi forrás. Ebben az áttekintö tanulmányban a dramatikus és szinházi nevelés eszközeivel történö empowerment folyamatra koncentrálok, felnöttek körében. Írásomban korábbi kutatások eredményeire támaszkodom.

Az empowerment összetett folyamat, amelynek értelmezése nagyban kontextusfüggö, ezért az értékelése nem egyszerü. A kutatók óva intenek egy általános méröeszköz bevezetésétöl (Zimmerman, 1995). Dolgozatomban bemutatok kvantitativ, kvalitativ és kombinált értékelési módszereket, mint amilyen például a Pszichológiai Empowerment Skála (Akey et al., 2000), az Empowerment Értékelés (Fetterman, 2001), és az Empowerment Méröeszköz (Jupp et al., 2010),
\end{abstract}


figyelembe véve Wandersman és munkatársai alapelveit az empowerment értékeléséröl (Wandersman et al., 2005).

Kulcsszavak: empowerment beavatkozás, empowerment értékelése, empowerment mérés

\section{Introduction}

Empowerment is still a buzzword in contexts such as social work, community development, psychology, and medicine. Empowerment is a process during which a person, an organization, or a community is enabled to identify themselves, to recognize their own power positions, and to improve their unequal social situations (Varga, 2017). In other words, it is ,an increase in power, (...) control or a real ability to effect change" (Ibrahim \& Alkire, 2007: 10). This review article focuses on the empowerment of adults through educational theatre and drama and is based on the analysis of previous research results in the area.

The evaluation of empowerment outcomes is missing from the Hungarian professional literature. In this article I present a brief overview on the available instruments. My selection criteria for determining the items included in the review were 1) relevance and 2) accessibility through the subscription provided by the University of Pécs. The resulting 20 publications describe specific evaluation measurements and instruments that, among other themes, include empowerment-related items. Some other measures investigate empowerment in specific contexts, such as workplace or health care environments. I mainly concentrated on the evaluation of empowering interventions, also pointing out a few methods that evaluate the actual level of empowerment without any prior intervention.

First, I provide a short summary on empowerment theories and on empowering interventions. Afterwards, I discuss the challenges and suggested principles of evaluating empowerment interventions. Then I move on to the domains and indicators that the different studies use when they evaluate empowerment, and subsequently, I present quantitative, qualitative, and mixed evaluation methods. Finally, I share my general conclusions. ${ }^{1}$

\section{Empowerment interventions}

Empowerment can be interpreted differently in the different contexts, what requires a contextual approach on part of the researcher. Zimmerman (2000) differentiates empowerment (or empowering) processes and empowerment (or empowered) outcomes in his empowerment theory. An empowerment intervention is an empowering process, for example, a community development project, a movement, or an adult educational program, etc. with the main goal of enabling participants to become more aware and critical of their social contexts, to be better at expressing their needs and opinions, and ultimately, to reach their individual or common goals, solve problems and make own decisions. ,The process is empowering if it helps people develop skills so they can become independent problem-solvers and decision-makers" (Zimmerman, 2000: 46). As Julian Rappaport commented, „empowerment is viewed as a process: the mechanism by which people, organizations, and communities gain mastery over their lives" (Rappaport, 1987: 122). The goal of an empowering intervention is to reach a point when participants can "redefine their sense of self as empowered rather than powerless" (Greene et

\footnotetext{
${ }^{1}$ I conducted this research as a part of preparing for my PhD thesis with the working title Empowerment through educational theater and drama among adults.
} 
al., 2005: 268). An empowered outcome is the result of an empowering project or program (Zimmerman, 2000).

Empowering interventions are built upon the perspective that the unequal distribution of power and resources is the source of numerous social problems. This approach focuses on identifying the strengths of the individuals, organizations, and communities, and promoting mutual and self-help instead of introducing some quick fix by an external actor. Zimmerman (2000) and Rappaport (1985) stress that during an empowerment process, the facilitator does not endow the participants with abilities or powers, rather, they collaborate with the participants in partnership, where the facilitator's knowledge is a tool and a resource that the participants can utilize if needed. In this perspective, the professionals should be flexible and adapt their approaches to the particular people, places, and cultures. The participants take an active part not only in the implementation, but also in the planning phase, and possibly, in the evaluation of the project (Zimmerman, 2000).

An empowerment intervention can happen on several levels: on the individual, the organizational, and the community levels, which are all interconnected. The individual level of empowerment, also referred to as psychological empowerment, comprises three dimensions: the intrapersonal, the interactional, and the behavioral aspects. The intrapersonal dimension is one's self-esteem, their motivation, and perceived ability to affect their surroundings. The interactional dimension covers their ability to analyze their socio-political environment and to decide if it is worth to enter into a conflict of interest, further, how to reach certain goals in a set context. The behavioral dimension is used to discuss one's actions to represent their own or their community's interests. An empowered individual is typically persistent and efficient, they might not always make a perfect decision, but are always aware of their options to choose between fighting, giving up or waiting. A person who is not empowered might suffer from low self-esteem and a sense of external locus of control and is often in the state of learned helplessness. Their perceived image of self is inefficient, powerless, and incapable. They often lack or underuse their resources (Greene et al., 2005; Zimmerman, 1990, 1995, 2000).

Moving on to the organizational level, we need to differentiate between empowering organizations and empowered organizations. An empowering organization has an empowering effect on individuals through the activities and services they provide: for example, NGOs, or informal hobby and sports clubs. An organizational empowering intervention operates with shared responsibilities and leadership, with a supporting atmosphere, and offers possibilities to take part in decision-making. Empowered organizations are effective: they are often able to reach their goals, mobilize resources, and influence policy decisions (Zimmerman, 2000).

An empowering process on the community level tolerates diversity, leads to pluralistic leadership and stronger participation among residents (Zimmerman, 2000). An empowering intervention in community development is a process of learning and acting collectively with the support of a professional or a more experienced peer. An empowered community facilitates citizen participation in decision-making on open forums, grants equal opportunities and equal access to the community's resources. Based on the actual needs, it improves and adapts to the changing environment. Usually, there are both empowered and empowering organizations in an empowered community (Zimmerman, 2000). 


\section{The challenges and principles of evaluating empowerment}

Empowerment is a context-dependent, multi-level construct, hence, evaluating empowerment outcomes is challenging. "Attempts at measurement are often dismissed as anecdotal" (Jupp et al., 2010: 15). Zimmerman (1995) warns against creating a general measurement tool. Such an instrument usually has several dimensions, and it may happen that the organization demonstrates a marked increase in scores in one domain and none in another, due to a specific empowerment intervention. Jupp and her colleagues (2010) suggest recording all the changes, i.e., conduct a process evaluation. Methodological decisions include choosing between contextspecific and universal, individual and collective, intrinsic and instrumental, quantitative and qualitative, participant-lead and external evaluation (Narayan, 2005, as cited in Ibrahim \& Alkire, 2007). A universal measure can only be applied if the contexts of the empowering processes correspond to one another (Holden et al., 2005). Several researchers believe that external evaluation is inherently erroneous, and "the art of measuring someone else's empowerment is potentially disempowering" (Taylor, 2000, as cited in Jupp et al., 2010: 35). Cross et al. (2017) suggested investigating the absence of empowerment instead of the concept itself, or to turn to established measures of participation, which is seen as a central theme to empowerment. Evaluating an empowerment intervention is highly problematic, since the expectations of the participants, the organizers and the funders differ greatly, and most methods can satisfy either one or another party - but not all the stakeholders. Even using participatory methods can prove to be troublesome, since empowerment is a moving target. Participants may interpret it differently from the beginning of an intervention to its later stages (Jupp et al., 2010). Empowerment scored 4 out of 5 in testability on the Theory Evaluation Scale, which means that even if evaluation has some limitations, such studies are feasible (Joseph, 2019).

According to Zimmerman $(1995,2000)$ the evaluation process should implement combined qualitative and quantitative methods, and it should be a participatory research. The participants should have access to the results so that they can use them when they want to influence policymakers. This seems to be in contradiction to some of Zimmerman's other works, where he suggests and applies non-participatory, quantitative methods (Eisman et al., 2016; Zimmerman \& Zahniser, 1991). Rappaport (1987) recommended a longitudinal investigation on evaluation. Jupp and associates (2010) claimed that the evaluation should be built on local contexts and experiences, and the participants should simply report all the changes without referring to any expected outcome. Cyril and associates (2015) suggested using qualitative or mixed methods for evaluating interventions on organizational and community levels. Cross and associates (2017) proposed evaluating community-level empowerment outcomes related to policy changes, but understood that this was challenging, since the changes might follow the interventions only years later. I have not encountered any specific suggestions regarding the participatory evaluation of individual empowerment. Most of its measures are quantitative, and the data is collected by external evaluators.

Wandersman and associates (2005) proposed the following principles for empowerment evaluation: the community should define all aspects of the evaluation process, and all stakeholders should participate directly in the evaluation. The process should be transparent and hold the evaluators accountable. It should facilitate authentic collaboration, and the tools developed should reflect the knowledge and wisdom of the community. It must appreciate scientific evidence and improvement, and the evaluation process itself should also contribute to the fair division of power and resources, and should transform the organization's and/or community's culture. However, these principles were created for empowerment evaluation, 
which is a participatory evaluation method created by Fetterman (2001), that is empowering as an evaluation method, but it does not evaluate empowerment itself. I am going to explicate this more in section "Available tools of evaluating empowerment interventions", but I would like to disclose at this point that this is the reason for me abstaining from using the phrase „empowerment evaluation" when discussing the evaluation of empowerment in this paper.

\section{Domains and indicators of empowerment}

Empowerment happens on different levels - individual, organizational, community, and under different social and cultural circumstances, having different generally empowering and domainspecific goals. Due to that, the domains and indicators of the evaluation vary greatly in the literature.

As I have mentioned earlier, Zimmerman's (1995, 2000) model of psychological empowerment consists of three dimensions: intrapersonal, interactional, and behavioral. The Sociopolitical Control Scale, created by Zimmerman \& Zahnisher (1991), is used often for measuring the intrapersonal component. Peterson and associates (2006) tested the original and the revised scale with confirmatory factor analysis, and concluded that using the revised scale with purely positively formulated items strengthens the validity of studies. Holden and associates (2005) claim, that changes in attitude and beliefs, agency, and knowledge of accessible resources indicate that psychological empowerment has occurred as a result of an intervention. Christens (2012, as cited in Eisman et al., 2016) offers another model of psychological empowerment that contains a relational dimension including collaborative competence, bridging in conflicting scenarios, network mobilization, and contributing to the empowerment of others. According to Cross and associates (2017), self-esteem, feeling of control, decision-making, self-determination, and mastery are indicators of individual empowerment. Speer \& Peterson (2000) applies the following dimensions: emotional, cognitive, and behavioral. Kasmel \& Tanggaard (2011) use five dimensions: self-efficacy, participation, motivation, and critical awareness measuring individual community-related empowerment. After validating their tool, Kasmel \& Tanggaard (2011) conclude that selfefficacy is the strongest dimension. Giving only one domain-specific example, Thomas \& Velthouse (1990, as cited in Batool \& Batool, 2017) identified four domains of workplace empowerment: meaning, competence/self-efficacy, choice, impact. Leonhauser (2005, as cited in Batool \& Batool, 2017) added coping as one more domain.

On the organizational and community levels, we can find indicators as being wellinformed, feeling critically engaged in the organization/community, capability to influence others used for Social Accounting and Auditing (Jupp et al., 2010). The Empowerment Monitoring Tool is applied with 132 indicators which pertain the following dimensions of empowerment: political, social, economic and natural resources, capability (Jupp et al., 2010). There are even tools for evaluating the actual level of empowerment on the level of regions or countries. They operate with indicators such as opportunity, use of opportunity, outcome of using opportunity (Alsop \& Heinsohn, 2005, as cited in Jupp et al., 2010). Measures of women's empowerment on this level may include indicators as the number of women in government or leadership, etc. (Jupp et al., 2010) Ibrahim \& Alkire (2007) propose that empowerment is an extension of agency, and choose the following indicators: empowerment as control, as choice, in community, as change on the individual and the communal level. 


\section{Available tools of evaluating empowerment interventions}

Several instruments and methods are available to evaluate empowering inventions. There are far fewer instruments for the organizational and community levels of empowerment than for the individual level, probably because most empowerment-related studies focus on the individual level as well. The measures of psychological empowerment are mainly inspired by western individualistic values, like self-determination, rights-based decision-making, and independence (Cyril et al., 2015; Zimmerman, 2000). Most of the resources that I have covered uses quantitative measures for evaluating empowerment outcomes, generally using surveys in a longitudinal study. Qualitative studies apply ethnographic, narrative and phenomenologist approaches, or case studies (Joseph, 2019). Zimmerman (1995) proposes mixed methods research. Mixed methods are often the combination of a survey and case studies or narratives (Jupp et al., 2010).

\section{Quantitative studies}

There are numerous quantitative measurement tools, and several studies review and test them for validity, like Cyril et al. (2015), Herbert et al. (2009), or Bakker \& Van Brakel (2012), though all these studies reassess health-related empowerment measures, so they may appear irrelevant to my search for a general empowerment measure. At the same time, empowerment is directly connected to wellbeing (Cyril et al., 2015), and this way, the papers that these studies include evaluate non-specific empowerment as well. The Psychological Empowerment Scale (Akey et al., 2000, as cited in Cyril et al., 2015) is a general evaluative survey of individual level empowerment and was tested as excellent. Eisman and associates (2016) tested Zimmerman's $(1995,2000)$ model of psychological empowerment. They used a survey containing items that tested the intrapersonal, interactional, and behavioral domains of the concept, furthermore, they added items investigating aggressive and prosocial behavior. Their results supported Zimmerman's model. Most surveys use items generated by external researchers and evaluators, but there are a few, which involve the participants in creating their survey, e.g., Hashem \& Schuler (1993, as cited in Jupp et al., 2010). Ibrahim \& Alkire (2007) propose a survey for international comparison of household empowerment, using both objective and subjective questions.

The aforementioned empowerment evaluation (Fetterman, 2001) may be considered a participatory evaluation method of organizational or community empowerment, utilizable both for interventions and for assessing the actual level of empowerment. In our personal correspondence, Fetterman (personal communication, March 16, 2020) claimed that empowerment evaluation was fit for assessing improvements in empowerment over time. However, according to Kasmel \& Tanggaard's (2011) critique, the advantages of the method are that it's clear and pragmatic, nonetheless, it cannot evaluate empowerment itself. His method monitors progress over time by the means of collaborative evaluation and planning based on the actual values assigned by the stakeholders to the different activities of a certain organization, community, or project. In Fetterman's book (2001) there is no mention of evaluating empowerment itself.

Numerous surveys have been created specifically for evaluating work- and healthrelated empowerment, some of them measuring the actual levels, and some evaluating the interventions. Examples for work-related empowerment measures are the Leader Empowering Behavior, Role Clarity and Psychological Empowerment Scale (Konczak et al., 2000, as cited in Batool \& Batool, 2017), the Global Psychological Empowerment Scale for Women (Batool 
\& Batool, 2017), the Scale of Psychological Empowerment among School Teachers (Wang \& Zhang, 2012, as cited in Batool \& Batool, 2017), and Social Workers' Empowerment Scale (Frans, 1993, as cited in Cyril et al., 2015). Health-related surveys evaluating empowerment are also plentiful, for example, Rissel et al. (1996, as cited in Cyril et al., 2015), Kasmel \& Tanggaard (2011), and Holden et al. (2005). Laverack's parallel tracks method is atypical as it facilitates a participatory quantitative evaluation combining the measurement of domainspecific progress and general empowerment on community level (Laverack \& Labonte, 2000). This approach uses a matrix like Fetterman's (2001), presenting the values attributed to domainspecific and empowerment-related statements. The evaluation process itself is empowering, again, similarly to Fetterman's (2001) empowerment evaluation. The parallel tracks evaluation makes both participants and organizers aware that the domain-specific goal around healthpromotion and empowerment as a goal are not the same, even though they are interconnected and their progress spill over. It evaluates improvement over time, without strict prior expectations about the nature of those improvements (Kasmel \& Tanggaard, 2011; Laverack \& Labonte, 2000).

\section{Qualitative studies}

There are relatively few research articles applying solely qualitative methods. Stacki \& Monkman (2003) used case studies of women in Latin-America and South-Asia. Gibbs and associates (2018) employed focus-group discussions with participants of Women for Women International Intervention in Afghanistan. Lyndon and associates (2011) introduced a phenomenological approach to explore the lived experience of the participants in a long-term program to combat poverty in Malaysia. They conducted in-depth interviews with additional, non-participant observations.

\section{Mixed methods}

Several authors (Bordy et al., 2015; Carrasco et al., 2016; Teddlie et al., 2009; Cyril et al., 2015; Joseph, 2019) apply combined, qualitative-quantitative evaluation methods. A positive example of mixed methods research is Social Accounting and Auditing: stakeholders' stories are used to describe the outcomes of the project (Jupp et al., 2010). Moyo (2015) investigated a donoraided project in Zimbabwe using household interviews, focus-group discussions, project reports, and surveys to evaluate the participants' psychological empowerment.

Jupp and associates (2010) created the Empowerment Monitoring Tool for assessing the empowerment progress of members of a social movement in Bangladesh. As development professional Robert Chambers put in in the study's preface, it was a "methodological breakthrough" (Jupp et al., 2010: 9). In the first stage of the evaluation process they used Participatory Rural Appraisal, a structured method with tools such as drama, drawing, storytelling, etc., to look for themes in community interpretations related to the transformations experienced through participation in the movement. Then they formulated statements based on the themes, which were subsequently validated by the members of the community. The statements served as the baseline for monitoring progress. The participants in the movement gathered every year to re-evaluate the statements, showing either a happy or an unhappy face to indicate whether their member organization is satisfied with that particular activity or approach. As a next step, they collected the statements with participants' additions. External evaluators summarized the results and generated the actual Group Development Index, informing not only about general progress but also about progress in the specific domains of 
empowerment in terms of political, social, economic, and natural resources, and capabilities. The local community combined the annual evaluation with discussions and planning for the future. The Empowerment Monitoring Tool represents the interests of all stakeholders. The members of the Movement in Bangladesh claim that their progress has sped up since they started using this method to evaluate progress (Jupp et al., 2010).

\section{Conclusion}

In the literature that I have covered I have encountered a dominance of quantitative, nonparticipatory evaluation methods, despite the frequent suggestions to use mixed methods in evaluating empowering interventions. As a conclusion, while participatory evaluation methods could work well on organizational and community levels, they may not be appropriate to measure the individual level.

\section{References}

Bakker, L. \& Van Brakel, W. H. (2012). Empowerment assessment tools in people with disabilities in developing countries: A systematic literature review. Leprosy Review, 83(2), 129-153.

Batool, S. A. \& Batool, S. S. (2017). Construction and validation of Global Psychological Empowerment Scale for Women. Pakistan Journal of Social and Clinical Psychology, 15(1), 3-10.

Cross R., Woodall J. R., Warwick-Boothe, L. (2017). Empowerment: does it measure up? Global Health Promotion Journal, July. https://www.doi.org/10.1177/1757975917703304

Eisman, A. B., Zimmerman, M. A., Kruger, D., Reischl, T. M., Miller, A. L., Franzen, S. P. \& MorrelSamuels, S. (2016). Psychological empowerment among urban youth: Measurement model and associations with youth outcomes. American Journal of Community Psychology, 58(3-4), 410421. https://www.doi.org/10.1002/ajcp.12094

Fetterman, D. (2001). Foundations of Empowerment evaluation. Sage Publications.

Gibbs, A., Jewkes, R., Karim, F., Marofi, F. \& Corboz, J. (2018). Understanding how Afghan women utilise a gender transformative and economic empowerment intervention: A qualitative study. Global Public Health, 13(3), 1-11. https://www.doi.org/10.1080/17441692.2018.1427276

Greene, G. J., Lee, M. Y. \& Hoffpauir, S. (2005). The languages of empowerment and strength in clinical social work: A constructivist perspective. Families in Society, 86(2), 267-277.

Herbert, R., Gagnon, A.J., Rennick, J. E. \& O'Loughlin, J. L. (2009). A systematic review of questionnaires measuring health-related empowerment. Research and Theory for Nursing Practice: An International Journal, 23(2), 107-132.

Holden, D. G. \& Evans, D. (2005). Modeling psychological empowerment among youth involved in local tobacco control efforts. Health Education \& Behavior, 32(2), 264-278. https://www.doi.org/10.1177/1090198104272336

Ibrahim, S. \& Alkire, S. (2007). Agency \& empowerment: A proposal for internationally comparable indicators. OPHI Working Paper Series.

Joseph, R. (2019). The theory of empowerment: A critical analysis with the theory evaluation scale. Journal of Human Behaviour in the Social Environment, 30(2), 138-157.

Jupp, D. \& Ali, S. I. (2010). Measuring empowerment? Ask them: Quantifying qualitative outcomes from people's own analysis. Sida. https://publikationer.sida.se/contentassets/fdf5b13132af4dddab45285c87980e1a/14962.pdf

Kasmel, A. \& Tanggaard, P. (2011). Evaluation of changes in individual community-related empowerment in community health promotion interventions in Estonia. International Journal of Environmental Research and Public Health, 8(6), 1772-1791. 


\section{Vojtek: Evaluation approaches to empowering interventions}

Lakatos, K. (2010). A képessé tétel (empowerment) lehetőségei a civil társadalomban. Civil Szemle, $7(2), 43-60$.

Laverack, G. \& Labonte, R. (2000). A planning framework for community empowerment goals within health promotion. Health Policy and Planning, 15(3), 255-262.

Lyndon, N., Moorthy, R., Er, A. C. \& Selvadurai, S. (2011). Native understanding of participation and empowerment in community development. Journal of Social Sciences, 7(4): 643-648. https://www.doi.org/10.1093/heapol/15.3.255

Mthokozisi, M. (2015). An assessment of psychological empowerment of donor aided projects on rural communities of Insiza District, Zimbabwe. Midland State University.

Peterson, N., Andrew, L., John B., Hughey, J., Reid, R. J., Zimmerman, M. A. \& Speer, P. W. (2006). Measuring the intrapersonal component of psychological empowerment: Confirmatory factor analysis of the Sociopolitical Control Scale. American Journal of Community Psychology, 38(34), 287-297.

Rappaport, J. (1987). Terms of empowerment/exemplars of prevention: Toward a theory for community psychology. American Journal of Community Psychology, 15(2), 121-148.

Speer, P. W. \& Peterson, N. A. (2000). Psychometric properties of an empowerment scale: Testing cognitive, emotional, and behavioural domains. Social Work Research, 24(2), 109-118.

Stacki, S. L. \& Monkman, K. (2003). Change through empowerment processes: Women's stories from South Asia and Latin America. Compare: A Journal of Comparative and International Education, 33(2), 173-189.

Varga, A. (2017). Inkluzivitás napjainkban: Hátrányos helyzetü, roma/cigány fiatalok életútja. Educatio, 26(3), 418-430.

Wandersman, A., Snell-Johns, J., Lentz, B. E., Fetterman, D. M., Keener, D. C. \& Livet, M. (2005). The principles of empowerment evaluation. In D. M. Fetterman \& A. Wandersman (Eds.), Empowerment evaluation principles in practice (pp. 27-41). Guilford

Zimmerman, M. A. (1990). Taking aim on empowerment research: On the distinction between individual and psychological conceptions. American Journal of Community Psychology, 18(1), 169-177.

Zimmerman, M. A. \& Zahniser, J. H. (1991). Refinement of sphere-specific measures of perceived control: Development of a sociopolitical control scale. Journal of Community Psychology, 19(2), 189-204.

Zimmerman, M. A. (1995). Psychological empowerment: Issues and illustrations. American Journal of Community Psychology, 23(5), 581-599.

Zimmerman, M. A. (2000). Empowerment theory: Psychological, organizational and community levels of analysis. In J. Rappaport \& E. Seidman (Eds.), Handbook of community psychology (pp. 4363). Kluwer Academic/Plenum Publishers. 